\title{
The Primary Source
}

Volume 32 | Issue 2

Article 3

2013

\section{Southern Cross of Honor Records at the Mississippi Department of Archives and History}

Jeff T. Giambrone

Mississippi Department of Archives and History

Follow this and additional works at: https://aquila.usm.edu/theprimarysource

Part of the Archival Science Commons

\section{Recommended Citation}

Giambrone, Jeff T. (2013) "Southern Cross of Honor Records at the Mississippi Department of Archives and History," The Primary Source: Vol. 32 : Iss. 2 , Article 3.

DOI: $10.18785 /$ ps.3202.03

Available at: https://aquila.usm.edu/theprimarysource/vol32/iss2/3

This Article is brought to you for free and open access by The Aquila Digital Community. It has been accepted for inclusion in The Primary Source by an authorized editor of The Aquila Digital Community. For more information, please contact Joshua.Cromwell@usm.edu. 


\section{Southern Cross of Honor Records at the Mississippi Department of Archives \& History}

Jeff T. Giambrone, Historic Resources Specialist at the Mississippi Department of Archives \& History in Jackson, Mississippi.

Some of the most widely requested records at the Mississippi Department of Archives and History are those related to the State's participation in the American Civil War. The service records of Mississippians who served in the Confederate army, their postwar pension applications, and the list of veteran grave registrations are all frequently used by researchers. In addition to the above mentioned records, there is an often overlooked resource at the archive that might be helpful to someone researching a relative that fought for the Confederacy: the United Daughters of the Confederacy (Mississippi Division) Southern Cross of Honor Records. ${ }^{1}$

The Southern Cross of Honor was a bronze Maltese cross suspended from a bar to which the recipients name could be engraved. The decoration was awarded by the United Daughters of the Confederacy to any Confederate veteran that served honorably as a soldier or sailor. The idea for the cross came from Mary Cobb Erwin, who was a member of the United Daughters of the Confederacy chapter in Athens, Georgia. The United Daughters of the Confederacy authorized the crosses in 1899 , and the first medals were awarded on Confederate Memorial Day, April 26, 1900. ${ }^{2}$

\footnotetext{
${ }^{1}$ United Daughters of the Confederacy (Mississippi Division), Southern Cross of Honor Records, 1900 1918. Located at the Mississippi Department of Archives \& History, Jackson, MS. Catalog \# Z/1907.000. Cited hereafter as Cross of Honor Records.

${ }^{2}$ Gregg S. Clemmer, Valor in Gray (Staunton, VA, 1998), 433-434.
} 
When the United Daughters of the Confederacy authorized the Cross of Honor, they selected three dates on which they could be bestowed. The first was Confederate Memorial Day, celebrated in Mississippi on April 26. ${ }^{3}$ The others were Jefferson Davis' birthday, June 3, and Robert E. Lee's birthday, January 19. In addition, each state chapter of the organization could choose one date between July 1 and January 19 to award crosses. Mississippi picked October 20, the birthday of "The Great Commoner," Senator J.Z. George. ${ }^{4}$

The Cross of Honor was a very powerful symbol to the veterans that received it, and they wore it with pride. Mrs. S.E.F. Rose, historian of the Mississippi Division of the United Daughters of the Confederacy, explained what the medal meant to the old soldiers that had earned the right to wear it:

It stands not for one deed of courage, but many. Not once, but often, these heroes in Gray faced death before the blazing cannon's mouth. Through the storm of hissing minnies, in the lonely watch of the midnight picket with no companion but the stars, and endured every form of hardship, peril and privation, and suffered the bitterness of cold, weariness and hunger. Yes, the Southern Cross of Honor has a deep significance - and 'this little bronze cross' that rests over the hearts of veterans tells its own story...To the veteran, it is a badge of merit - justly won, for he has paid the price and earned the right to wear it on many a bloody battlefield. ${ }^{5}$

The Southern Cross of Honor records at the Mississippi Department of Archives \& History are contained in two bound volumes, and cover the years from $1900-1918$; however the majority of the records date from 1907 - 1918. Each volume contains a wealth of information about the individual recipient of a Cross of Honor: the name of the soldier, his rank, the company and regiment that he served in during the war, his period

\footnotetext{
${ }^{3}$ The Mississippi Code of 1906 (Nashville, TN, 1906), 1104.

4 "History of the Southern Cross of Honor," Confederate Veteran Magazine, Volume XVIII (January

1910), No. 1, 234 - 235. “Crosses of Honor,” Daily Herald (Biloxi, MS), 20 September 1904.
} 
of service, the United Confederate Veterans camp he belonged to, the United Daughters of the Confederacy camp bestowing the cross, and the name of the soldier's next of kin is among the information included. ${ }^{6}$

Unfortunately, the Southern Cross of Honor Records have never been widely utilized by Civil War researchers, as the information is not easy to access. The first book alone has 1,043 individual veterans listed, and the second book is of a similar size. Neither book is indexed, requiring a researcher to look through each book name by name to try and find the person they are seeking. In addition, both books are extremely fragile, and can not withstand repeated handling by patrons.

To make these documents more user friendly, a project is currently underway at the archives to transcribe these records into a computer database that will eventually be available to patrons. This will be a boon to those doing Civil War research, as the Cross of Honor records have information in them that may be available nowhere else. For example, one veteran listed in the records is Charles B.N. Rice of Copiah County. He was presented his medal on April 26, 1914, by the Charles E. Hooker Chapter, United Daughters of the Confederacy, in Hazlehurst, Mississippi. Rice listed his unit on the application as "Member of the home guard," a group which has little or no official documentation at the archives. He does not have a service record, did not file for a veteran's pension, and does not show up on the Mississippi Confederate grave

\footnotetext{
${ }^{5}$ Mrs. S.E.F. Rose, "Southern Cross of Honor," Our Heritage, Volume IV, No. 12, (October 1910). Located in the Southern Cross of Honor Subject File, Mississippi Department of Archives \& History, Jackson, MS.

${ }^{6}$ Cross of Honor Records.
} 
registration cards. Rice's Cross of Honor application may be the only written record of his wartime service. ${ }^{7}$

The Cross of Honor applications had a space reserved to list the recipient's next of kin, but it was not always filled out. For the veterans that did list a relative, however, this information may prove to be very useful to a researcher. When Joseph H. Askun applied for his cross, his listed his next of kin as "Mrs. Frank C. Owen \& Mary A. Owen, daughters." George W. Harris listed his nearest relative as "S.P. Harris, son, Verona, Miss."

Some of the Cross of Honor listings have additional information added that can provide useful insights into the wartime service or postwar life of the veteran. On the application of William J. Byars there is a notation that he "Died Meridian, Jan. 19" 1909." E.H. Gregory's listing notes that he was "Honorably discharged Columbus, Miss., on leave of absence caused by wounds, May 1865." A.C. Minter had to apply for a replacement cross, and it was noted that "Mr. Minter lost his first cross when his home burned Jan. 19, 1914."

In addition to the information contained in the Cross of Honor records, staff members at the Mississippi Department of Archives \& History are attempting to verify the information in the books by checking it against the veterans service records, pension applications, and grave registration cards. This is necessary because in many instances the veteran only wrote down the name of his commander, or the name of the company he served in, not the regiment he was attached to. For example, C.H. McLeod only listed his unit as "Co. A, Stockdale's Battalion Mississippi Cav. Vols.” A quick check of Grady

\footnotetext{
${ }^{7}$ Ibid.

${ }^{8}$ Ibid.
} 
Howell's seminal roster of Mississippi Confederate soldiers indicates that McLeod served in Company A, $4^{\text {th }}$ Mississippi Cavalry. Armed with this information, a family genealogist could determine which battles the $4^{\text {th }}$ Mississippi Cavalry fought in, and gain a better understanding of the service of C.H. McLeod. ${ }^{10}$

The information in the Cross of Honor records can indicate new sources that a researcher might want to check out. Using the date of bestowal of the cross, a researcher could check the veteran's hometown newspaper to see if the publication wrote an article about the award ceremony. One of the men listed on the Cross of Honor records is James M. Selser, a relative of the author who served in the $1^{\text {st }}$ Mississippi Cavalry. He was awarded his cross in Hattiesburg, Mississippi, on April 26, 1913. ${ }^{11}$ A search of the Hattiesburg newspaper turned up an article about the event, listing every man by name that was awarded a cross. The paper also gave a detailed description of the ceremony:

Mrs. Massengale, the church organist, played a stirring march as the procession filed into the church. Captain J.P. Carter, commandant of the local camp of veterans, called on Dr. E.J. Currie to lead in prayer, at the conclusion of which the audience sang a hymn, which was followed by a presentation of crosses of honor by Mrs. Wm. F. Hewett, who said there are three important events in the life of the soldier, the call to arms, the surrender and the bestowal of the cross of honor. ${ }^{12}$

The project to transcribe the Cross of Honor records is underway: the records from the first book have been entered into a computer database, along with the information found by the staff at the archives when verifying the service of each soldier. Data entry on the second book will begin soon. This is a time consuming process, but eventually the database will be made available to the public. This database will be

\footnotetext{
9 Ibid.

${ }^{10}$ H. Grady Howell, Jr., For Dixie Land I'll Take My Stand! A Muster Listing of All Known Mississippi Confederate Soldiers, Sailors and Marines, Volume 2. (Madison, MS, 1998), 1913.

${ }^{11}$ Cross of Honor Records.
} 
searchable by name or by unit, and will prove a valuable resource to those doing Civil War research on an ancestor that served in a Mississippi unit.

12 “Observance of Memorial Day,” The Weekly News (Hattiesburg, MS), 2 May 1913. 